ISSN: 2224-0616

Int. J. Agril. Res. Innov. \& Tech. 6 (1): 8-13, June, 2016

Available online at http:// www.ijarit.webs.com

\title{
ANALYSIS OF EFFICIENCY AND FACTORS AFFECTING THE PRODUCTION OF CABBAGE FARMING (Brassica oleracea L.) IN BELUNG VILLAGE, PONCOKUSUMO, MALANG, INDONESIA
}

\section{G.M. Ningsih}

Received 23 January 2016, Revised 28 May 2016, Accepted 21 June 2016, Published online 30 June 2016

\begin{abstract}
The purpose of this research was to analyze the efficiency and the factors that affect the production of cabbage farm in the village of Belung, Poncokusumo, Malang, Indonesia. Samples taken by census the number of respondents 36 farmers. The analysis used is descriptive qualitative and quantitative. Quantitative analysis include analysis of costs, revenues, income, efficiency and Cobb-Douglas. Based on the analysis, known that farmer acceptance is Rp. 43,767,361 and generated revenues of Rp. 30,124,372/ ha. Result relevated that the Cabbage farm in the village of Belung, Poncokusumo, Malang was highly efficient and profitable with an efficiency of 3.2. Factors that effect significantly on cabbage farming production are labors, lands, pesticides and seeds. Input combinations are already efficient and optimal pesticides and seeds.
\end{abstract}

Keywords: Adopter, Agroforest, Cocoa, Logit Model, Odds Ratio

Lecturer, Department of Social Economics of Agriculture, Faculty of Agriculture, Animal Husbandry Muhammadiyah University of Malang, Indonesia

*Corresponding author’s email: gumoyo.umm@gmail.com (G.M. Ningsih)

\section{Introduction}

Vegetables are not only beneficial for their contribution for the share of agriculture in the economy of swaziland, but also have a significan probability to compete where there are fewer government regulation and restriction in the economy. Curently, the local demand for vegetables is higher than local production and hence the gap is filled by imports from SouthAfrica. The factors that significantly affected productivity of vegetable farmers were access to credit, selling price, fertilizer, quantity, distance to market and gender of the farmer (Masuku, 2013).

Indonesia is an agricultural country that the majority of people working in agriculture, or working as farmer. The farmers in Indonesia in general did not have a record of good farming and regular, whereas the advanced agriculture is characterized either by the input-output recording of farming.

Geographically Belung Village is an area with soil conditions form of landscape that tend hilly because located on the west slopes of Mount Semeru, mostly productive land. The village is located at an altitude between 600-1200 meters above sea level with an average rainfall of between $2300 \mathrm{~mm}$ to $2500 \mathrm{~mm}$ per year and an average temperature of 21.7 derajat. The majority livelihood Belung village is petani. It is supported by soil farm factors. A land fertile for agricultural commodities in the village one is plant cabbage. Cabbages included in one type of leaf vegetable crop that has the potential to be developed, because in addition to meet domestic demand, cabbage also has potential as an export commodity. Planting cabbage in large Belung partially village by farmers who are local residents. The cropping pattern is done intercropping, usually cabbage plant extracted with chili or tomato plants. However, the cropping pattern is also adapted to the needs of the market, as a result of further farm will be sold to the regional market, domestic and international. Cabbage production process includes tillage, nursery, planting, maintenance and harvesting.

The problem that occurs is the existing practice in the use of farmers in farming production factors not dosed precisely and no recording, so farmers often did not attention to the costs incurred to manage production detail. Factors has resulted in the acquisition of the gains small farmers and even it was lose. It's made the researchers to conduct the research on the analysis of the efficiency and the factors that affect the production of cabbage farm in the village of Belung, Poncokusumo, District Malang, Indonesia. The purpose of this study were (1) to analyze the cost cabbage farm in the village of Belung, Poncokusumo, Malang, (2) analyze the efficiency of a cabbage farm in the village of Belung, Poncokusumo, Malang, (3) Analyze the factors that influence the production of cabbage production in the village Belung, Poncokusumo, Malang, Indonesia. 


\section{Methodology}

This research was conducted in the village of Belung, Poncokusumo, Malang on $11 \mathrm{~s} / \mathrm{d} 30$ October 2014. The location determined of the grounds in the area is a commodity-producing area of vegetables, especially cabbage is high enough. Besides that, Belung village lies in the area of mountain slopes semeru with an altitude of almost 1000 meters above sea level make this place suitable for growing a wide variety of vegetables, especially cabbage.

Sampling was done by propotional stratified random sampling that the number of respondents as many as 36 farmers in the village of Belung. The analysis method conducted by an analysis of qualitative and quantitative descriptive. Descriptive qualitative analysis is used to describe or depict a condition related to the research problem that cannot be described quantitatively, covering the geography of the study, the characteristics of the farmers, the state of the population and the state of cabbage farming in the study area. Quantitative analysis in this study is used to determine the level of costs, revenues and cabbage farm income, as well as determine the factors that influence the production of cabbage farm. The formula - the formula used in the calculation is as follows:

1. Determining Variable Cost (VC), Fixed Cost (FC), Total Cost (TC), Total Revenue (TR), Income, and $\mathrm{R} / \mathrm{C}$ ratio. Adapun $\mathrm{TC}$ calculation formula is as follows:

\section{$\mathbf{T C}=\mathbf{F C}+\mathbf{V C}$}

The calculation formula Receipts (THR) is as follows:

$\mathrm{TR}=\mathrm{p} \times \mathrm{q}$

Description:

$\begin{array}{ll}\text { TR } & \text { : Reception } \\ \mathrm{p} & \text { : Price } \\ \mathrm{q} & \text { : The amount of goods }\end{array}$

As for calculating the income that is by the formula:

$\pi=\mathbf{T R}-\mathbf{T C}$

Description:

$$
\begin{array}{ll}
\pi & \text { : Revenue } \\
\text { TR } & \text { : Reception } \\
\text { TC } & \text { : Total Cost }
\end{array}
$$

To calculate the $\mathrm{R}$ / $\mathrm{C}$ ratio, an analyzer to measure the cost of a production is as follows:

$\mathrm{R} / \mathrm{C}$ ratio $=\frac{\text { Total Rovenuse }}{\text { Total Cost }}$
Criteria:

$\mathrm{R} / \mathrm{C}$ Ratio $>1$, the farming efficient and profitable $\mathrm{R} / \mathrm{C}$ Ratio $<1$, the farming not efficient and profitable $\mathrm{R} / \mathrm{C}$ Ratio $=1$, the farming is break event

\section{Analysis of Factors Affecting Farming Cabbage}

The factors that affect farm production of cabbage can be known from the magnitude of the elasticity of Cobb - Douglas by using a data analysis program SPSS version 16.0 (Gujarati, 2007). Form Cobb - Douglas:

$$
\mathrm{Y}=\beta_{0} \mathrm{X}_{1}^{\beta_{1}} \mathrm{X}_{2}^{\beta_{2}} \mathrm{X}_{3}^{\beta_{3}} \mathrm{X}_{4}^{\beta_{4}} \mathrm{e}^{\mathrm{u}}
$$

Where:

$$
\begin{aligned}
& \text { Bo =intercept / constants } \\
& \beta_{1}=\text { coefficient of X1 Production } \\
& \beta_{2}=\text { coefficient of } X 2 \text { Production } \\
& \beta_{3}=\text { coefficient Production of the X3 } \\
& \beta 4 \quad=\text { coefficient of } X 4 \text { Production } \\
& \mathrm{X} 1=\text { Labor }(\mathrm{HOK}) \\
& \mathrm{X} 2=\text { Land Area (Ha) } \\
& \text { X3 = Fertilizer }(\mathrm{Kg}) \\
& \mathrm{X} 4=\text { Pesticides (Liter) } \\
& \mathrm{X} 5=\text { Seeds }(\mathrm{Kg}) \\
& \text { e } \quad=\text { Numbers } \\
& \mathrm{u} \quad=\text { Error (Disturbance Term) }
\end{aligned}
$$

In order for this production, function can be estimated, then the equation needs to be transformed into the form of a linear equation as follows:

$\operatorname{LnY}=\operatorname{Ln} \beta_{0}+\beta_{1} \operatorname{LnX} X_{1}+\beta_{2} \operatorname{LnX}_{2}+\beta_{3} \operatorname{LnX} X_{3}+\beta_{4} \operatorname{LnX}_{4}$ $+\beta_{5} \operatorname{LnX} X_{5}+u$.

Economic efficiency is achieved when the maximum profit is obtained. Profit obtained when the maximum is reached optimum combination of inputs, (Soekartawi, 2003). Requirements to obtain the maximum profit are as follows:

\section{$\mathbf{P x}=\mathbf{P y} . \mathbf{P M}$}

Means if:

$$
\begin{aligned}
& \text { Py } . M=1 \text { optimum imput combination } \\
& \frac{P_{y}}{P_{x}} \cdot P_{M}>1 \text { uptimum yet input combination }
\end{aligned}
$$

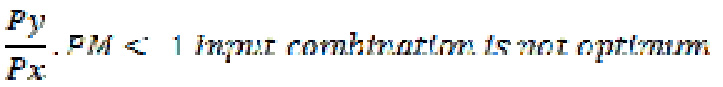

Of function is Cobb - Douglass is known that:

$$
P M_{X i}=B_{i} \frac{\boldsymbol{Y}}{X \boldsymbol{X}}
$$

Then the maximum profit is achieved if:

$$
\boldsymbol{P}_{X i}=\boldsymbol{B}_{i} \frac{\boldsymbol{Y}}{\boldsymbol{X} i}, \boldsymbol{P}_{y}
$$

Or optimum input combination, if: 


$$
B_{1}=\frac{Y \cdot P y}{X i \cdot P X_{i}}=1
$$

While each of the input $\left(\mathrm{X}_{1}\right)$ used for:

$$
\boldsymbol{x}_{i}=\frac{B i \cdot \boldsymbol{Y} \cdot \boldsymbol{P} \boldsymbol{y}}{\boldsymbol{P}_{X i}}=1
$$

Where:

$$
\begin{array}{ll}
\mathrm{Xi} & =\text { Wide input } \\
\mathrm{P}_{\mathrm{xi}} & =\text { Unity input prices are concerned } \\
\mathrm{Y} & =\text { Average production } \\
\mathrm{Py} & =\text { Price per unit of output (production) } \\
\mathrm{Bi} & =\text { Regression coefficient }
\end{array}
$$

\section{Discussion}

\section{Analysis of farming}

Cabbage farm analysis was conducted to determine the amount of costs incurred and determine revenue and efficiencies generated by cabbage farmer in the village of Belung, Poncokusumo, District Malang. The analysis used include cost analysis, revenue and income as well as R/ C Ratio.

\section{Variable cost}

Variable costs are costs which changed according to the level of production. Variable costs on cabbage plants include seed, fertilizer, pesticides and labor. The following data on the variable cost of cabbage farm in the village of Belung, Poncokusumo, Malang, Indonesia.

Table 1. Variable costs

\begin{tabular}{lcc}
\hline $\begin{array}{l}\text { Variable } \\
\text { costs }\end{array}$ & Amount (Rp) & $\begin{array}{c}\text { Percentage } \\
(\%)\end{array}$ \\
\hline Seeds & 185.417 & 8.15 \\
Fertilizer & 614.028 & 27.02 \\
Pesticide & 171.194 & 7.54 \\
Labor & 1.302 .063 & 57.29 \\
\hline Total & 2.272 .701 & 100 \\
\hline
\end{tabular}

Source: Primary data, processed in 2015

According to Table 1, it can be seen that the use of the highest variable cost is labor cost of the percentage rate $57.29 \%$ for a total cost of Rp. $1,302,063$. This is reasonable because labor costs include land preparation to cabbage harvesting. Labor costs calculated from the number of people working (HOK) multiplied by a given wage per effective HOK working hours for 6 hours in which workers usually start work from 06.00 am- 12.00 noon. Average labor is worker outside the family wage labor for 30,000 men and women Rp. 25.000. The processing of land for planting, the maintenance usually done by male labor force while the process of planting and harvesting done by women workers. The type of seed used is a hybrid type. This is because the hybrid seed is faster to harvest more resistant to pests and diseases, as well as its productivity is more than other types. Fertilizer types used include Cages fertilizer, Urea, NPK and TSP fertilizers. All of the fertilizer is used for fertilizing two times, namely when planting and planting maintenance. Pesticides used in farming cabbage to maximum growth and free from pests.

\section{Fixed cost}

Fixed costs are that the costs volume do not affect of the resulting output. This fixed cost covers the cost of taxes, depreciation of tools and irrigation.

Table 2. Fixed costs analysis

\begin{tabular}{lcc}
\hline Fixed cost & $\begin{array}{c}\text { Amount } \\
(\mathrm{Rp})\end{array}$ & $\begin{array}{c}\text { Percentage } \\
(\%)\end{array}$ \\
\hline Land lease & 10.000 .000 & 87,98 \\
Tolls depriciation & 1.270 .288 & 11,16 \\
Irrigation & 100.000 & 0,86 \\
\hline Total & 11.370 .288 & 100 \\
\hline
\end{tabular}

Source: Primary data, processed in 2015

The use of higher fixed costs is land lease which percentage rate of $87.98 \%$, or at a cost of $\mathrm{Rp}$. 10.000.000. The land lease, including the medium category, because the land is still in rural region so the price are not too high. The region is very suitable land planted with various kinds of vegetables because it lies on the slopes of Mount Bromo region. Agricultural land can be distinguished by farmland. Agricultural land is land used for farming, such as rice paddies, fields or yard. While farmland is land that is not always cultivated by agricultural production (Soekartawi, 1993). The type of land used for cabbage in the village Belung, Poncokusumo, Malang is dry land. The tools used in the farming of cabbage include hoes, sickles and sprayer. The use of agricultural land based on the availability of irrigation, it illustrates the kinds of cultivated plants, emphasizing the planting pattern. The closer to the irrigation, the cost of land lease will also be more expensive.

\section{Total cost}

The total cost is the total overall costs incurred by farmers. The total cost is derived from the sum of the variable costs and fixed costs.

Table 3. Total cost analysis

\begin{tabular}{lcc}
\hline Total Cost & Amount (Rp) & $\begin{array}{c}\text { Percentage } \\
(\%)\end{array}$ \\
\hline Variable cost & 2.272 .701 & 16,65 \\
Fixed Cost & 11.370 .288 & 83,35 \\
\hline Total & 13.642 .989 & 100 \\
\hline
\end{tabular}

Source: Primary data, processed in 2015 
The total cost of cabbage farming around Rp. 13,642,989/ ha. The total cost is derived from the sum of the variable costs and fixed costs. The variable cost of Rp. 2,272,701 and its fixed costs Rp. 11,370,288. The higher use of cost is the fix cost percentage rate of $83.35 \%$.

\section{Revenue}

Revenue is the gross income earned by farmers. Receipts obtained from cabbage production quantity multiplied by the price the farmer to the wholesaler.

Table 4. Acceptance of farm cabbage

\begin{tabular}{ll}
\hline Acceptance & Amount \\
\hline Production $(\mathrm{kg})$ & 43.750 \\
Price $(\mathrm{Rp})$ & 1.022 \\
\hline Total & 43.767 .361 \\
\hline
\end{tabular}

Source: Primary data, processed in 2015

The average production per hectare cabbage amounted to $43,750 \mathrm{~kg}$, and farmers selling to traders with an average price of Rp. 1,022/ kg, so the farmer aoceptance Rp. 43,767,361/ha.

\section{Revenues and revenue cost ratio}

Revenue is the net proceeds received by cabbage farmers, while the $\mathrm{R} / \mathrm{C}$ ratio is used to determine the efficiency of farming. The success of the cabbage farming can be seen from the economic efficiency which closely to the price of production. Efficient use of cost determined by using $\mathrm{R} / \mathrm{C}$ ratio analysis which is the ratio between total gross revenue with total costs used during the production process takes place (Sya'diyah, 2011). Here are the results of the calculation of revenue and $\mathrm{R} / \mathrm{C}$ ratio:

Table 5. Pendapatan dan $\mathrm{R} / \mathrm{C}$ ratio

\begin{tabular}{ll}
\hline Revenues & Amount (Rp) \\
\hline Acceptance & 43.767 .361 \\
Total Cost & 13.642 .989 \\
\hline Total & 30.124 .372 \\
\hline R/C Ratio & 3.2 \\
\hline
\end{tabular}

Source: Primary data, processed in 2015

The calculation of revenues obtained by farmers' gross revenues derived from deducting the total cost incurred, so that the average income of farmers cabbage Rp. 30,124,372/ ha. Farming efficiency can be obtained by calculating Revenue Cost Ratio ( $\mathrm{R} / \mathrm{C}$ ratio) comparing the revenue that the total cost issued. Efficiency value in cabbage farming known of 3.2, resulting from the criteria used is if the $\mathrm{R} / \mathrm{C}$ ratio $>1$, means the cabbage farm run efficiently and profitably. R/C ratio illustrates that for every 1 Rupiah of expenditure in the cabbage farm will generate 3.2 Rupiah.

\section{B. Analysis of cabbage farm production affecting factors}

Before the regression analysis, data is transformed into the shape of the natural logarithm (ln). Based on regression analysis it can be seen that correlation ( $\mathrm{R}$ ) value is equal to 0.998 where the value is $>0.5$ means that the relationship between the dependent variable (production) of the independent variable (labor, land, fertilizers, pesticides and seeds) is very strong. The coefficient of determination (R2) was conducted to determine the level of influence the dependent variable percentage of the independent variables. Based on the analysis results generated using SPSS version $16, \mathrm{R}^{2}$ value of 0.995 , meaning that $99.5 \%$ of the independent variables (labor, land, fertilizers, pesticides and seeds) effect on the dependent variable (production), while the remaining $0.5 \%$ affecting by others factor which not included in the research model.

F test is used to describe the relationship between production and the factors of production. Based on regression analysis performed, the value of $\mathrm{F}_{\text {count }}$ at 13.53 and $\mathrm{F}_{\text {table }}$ of 2.05 at $90 \%$ confidence level ( $\alpha: 0: 10)$. It means that factors of production (labor, land, fertilizers, pesticides and seeds) jointly significant effect on the production of cabbage in the village Belung, Poncokusumo, Malang Regency because $F_{\text {count }}>F_{\text {table. }}$.

Based on partial t-test using SPSS version 16 can be seen as the result of the calculation is contained in Table 6.

Table 6. Coefficient

\begin{tabular}{lcccc}
\hline Model & B & Sig & $T_{\text {count }}$ & $\mathrm{T}_{\text {table }}$ \\
\hline Constant & 10.541 & 0.000 & 39.658 & 0.13 \\
LnX1 (Labor) & 0.054 & 0.354 & 0.959 & \\
LnX2 (Land Area) & 0.957 & 0.000 & 20.568 & \\
LnX3 (Fertilizer) & 0.003 & 0.906 & 0.120 & \\
LnX4 (Pestisides) & 0.008 & 0.702 & 0.386 & \\
LnX5 (Seed) & 0.005 & 0.796 & 0.261 & \\
\hline
\end{tabular}

Source: Primary data, processed in 2015

The multiple regression equation can be done by interpreting the numbers in the unstandardized Coefficients particular column B. Based on equation formula model, the model of the equation can be written as follows:

$\mathrm{LNY}=\operatorname{Ln} \beta \mathrm{o}+\beta_{1} \operatorname{LnX} 1+\beta_{2} \operatorname{LnX} 2+\beta_{3} \operatorname{LnX}_{3}+\beta_{4} \operatorname{LnX} 4$ $+\beta 5 \operatorname{Ln} X_{5}+u$.

$\mathrm{LNY}=10,541+0.054 \mathrm{X} 1+0.857 \mathrm{X} 2+0.003 \mathrm{X} 3+$ $0.008 \times 4+0.005 \times 5$

T-test is done by looking $t_{\text {count }}$ and table. The confidence level used is 90\% ( $\alpha$ : 0.10 ) and the degrees of freedom (df) by $n-k$ formula is 30 , so that the value $t_{\text {tabel }} 0: 13$. Results of the t-test showed that labor X1 significant, because $t_{\text {count }}$ 
$(0.959)>t_{\text {table }}( \pm 0: 13)$. Based on the value $\beta 1$ (0.054) showed each additional $1 \%$ of the labor will be the addition of cabbage production in $0.054 \%$. It is suspected because of labor in the study area has a good management in agribusiness management.

T-value in land area amounts to 20,568 means that the value is very significant, while based on the value $\beta 2$ (o.957) showed each additional 1\% of land area it would add production output amounted to $95.7 \%$. This is because of the soil in the Belung village, Poncokusumo, Malang is very fertile and suitable for growing types of vegetables, so that more land under cultivation, the production will increase.

Value of fertilizer $\mathrm{T}_{\text {count }}$ is equal to 0.120 , means that the fertilizer did not significantly affect the production of cabbage. This is reasonable because if the fertilizer given too much the plants growth will be less good. In addition farmers ignore the dose of fertilizer use. Other factors affecting the fertilizer had no significant effect due to rainfall is high enough so the fertilizer applied does not optimally absorbed by cabbage plants.

$\mathrm{T}_{\text {count }}$ on pesticides is equal to $0.386>$ from $t_{\text {table, }}$ means that pesticides have real impact on the production of cabbage, while the value of $\beta 4$ (0.008) indicates that each additional 1\% of pesticides will increase the production of cabbage by $0.8 \%$.

$\mathrm{T}_{\text {count }}$ on the seed is at $0.261>$ from table, means that the seeds have real impact on the production of cabbage, while the value $\beta 5$ (ooo5) showed that each additional $1 \%$ seeds of cabbage production will increase by $0.5 \%$. Good quality seed will produce a good product, too. Farmers in the area of research using hybrid seed because this seed types generate more production than in other types of seed.

\section{Cabbage farm efficiency analysis}

Efficiency is the effort to achieve the goal by using a minimum of resources or optimal use of resources to achieve the maximum (Sarpintono, 2009).

a. Labor (X1)

$$
x_{i}-\frac{(0.054) x(30406.25) x(1022)}{(39) x(225000)}-0.2
$$

Based on the results of these calculations can be seen that the value is $<1$, so that the combination of the labor input is no longer optimum. While the optimal combination of inputs when employment reached 7, so that the average use of labor per hectare is 1 person/ ha. b. Land Area (X2)

$$
X_{i}=\frac{(0.957) x(30406.25) x(1022)}{(0.6) x(63194444)}=7.2
$$

Based on the results of these calculations can be seen that the value is $>1$, so that the combination of input on land area optimum yet. While optimal combination of inputs when reached 4.71 ha land area.

Land use is highly dependent on the state of the environment and the land is located (Wibisono, 2011). The size of the land area of the traditional need to be understood in order to be transformed to the size of the land area represented by hectare (Soekartawi, 1993).

$$
\begin{aligned}
& \text { c. Fertilizer (X3) } \\
& \qquad X_{i}=\frac{(0.003) x(30406.25) x(1022)}{(103.9) \times(6450)}=0.1
\end{aligned}
$$

Based on the results of these calculations can be seen that the value is $<1$, so that the combination of the fertilizer input is no longer optimum. While the combination of optimal input when reaching $14.45 \mathrm{~kg}$, so that the average use of fertilizer is $2,006 \mathrm{~kg} / \mathrm{ha}$.

$$
\begin{aligned}
& \text { d. Pesticides (X4) } \\
& \qquad X_{i}=\frac{(0.008) x(30406.25) \times(1022)}{(1.2) x(160000)}=1
\end{aligned}
$$

Based on the results of these calculations can be seen that the value is $=1$, so the combination inputs on pesticides already optimum.

e. Seeds (X5)

$$
X_{i}=\frac{(0.005) x(30406.25) x(1022)}{(183.9) x(6450)}=1
$$

Based on the results of these calculations can be seen that the value is $=1$, so the combination inputs on the seeds have been optimum.

\section{Conclusion}

The total cost issued by farmers is Rp. 13,642,989 this cost includes variable costs Rp. 2,272,701 and a fixed cost of Rp. 11,370,288. Acceptance of farmers is Rp. 43,767,361 and the revenues of Rp. $30,124,372 /$ ha. Cabbage farm in the Belung village, Poncokusumo, Malang highly efficient and profitable with an efficiency level of 3,2. Production factors have very significant effect on cabbage farming is labor, land, pesticides and seeds. Input combinations are already efficient and optimal pesticides and seeds. 


\section{References}

Gujarati, D. 2007. Basics Ekonometrics. Jakarta: Erlangga. 203p.

Masuku, M.B. 2013. Factors Affecting the Productivity and Profitability of Vegetables Production in Swaziland. J. Agric. Stud. 1(2): 37.

Sarpintono, 2009. Analysis of Efficient Factors Farm Kuda Corn (Zea mays Indentata) in the village of Bukit Barisan Merigi Kepahiang District. Thesis STIPER, Rejang Lebong Indonesia: pp. 11-19.
Soekartawi. 1993. Basic Principles of Agricultural Economics, Theory and Applications. J akarta: Grafindo Persada. 176p.

Soekartawi. 2003. Economic Theory of Production by Subject Function Analysis Cobb-Douglass. Jakarta: PT. Raja Grafindo Persada : 78p.

Sya'diyah. A.R. 2011 Economic analysis of farm cabbage in district Sukapura ProbolinggoIndonesia. Buana Sains. 11(2): 103-108.

Wibisono, H. 2011. Efficiency Analysis Cabbage Farm. Thesis School of Economics. Semarang: Diponegoro University. pp. 4562. 